\title{
A Two-Year Farm Management Survey of Greenbrier and Monroe Counties
}

\author{
A.J. Dadisman
}

Follow this and additional works at: https://researchrepository.wvu.edu/ wv_agricultural_and_forestry_experiment_station_bulletins

\section{Digital Commons Citation}

Dadisman, A. J., "A Two-Year Farm Management Survey of Greenbrier and Monroe Counties" (1920). West Virginia Agricultural and Forestry Experiment Station Bulletins. 173.

https://researchrepository.wvu.edu/wv_agricultural_and_forestry_experiment_station_bulletins/173 
West Virginia University Libraries

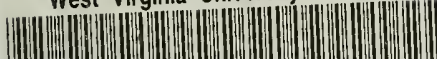

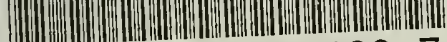

308021007621097 



\section{rrakst Virquinia OAnibersity Aquirultural Experiment Statín}

JOHN LEE COULTER, Director MORGANTOWN

\section{A Two-Year Farm Management Survey of Greenbrier and Monroe Counties}

DEPARTMENT OF FARM ECONOMICS

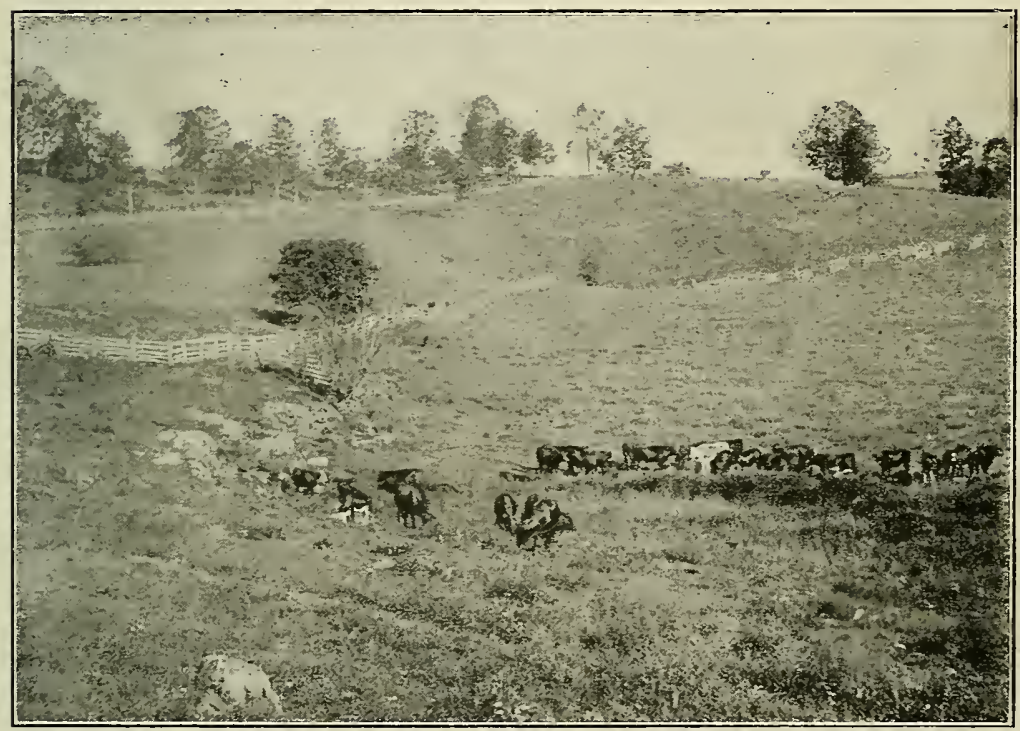

A Typical View of West Virginia's Bluegrass Country.

BY
A. J. Dadisman and C. F. Sarle

In Co-operation With the United States Department of Agricultur Office of Farm Management

Bulletins and Reports of this Station will be mailed free to any citizen of West Virgini; upon written application. Address Director of the West Virginia Igricultural Experiment Station, Morgantown, W. Va. 


\section{THE STATE OF WEST VIRGINIA}

Educational Institutions

\section{THE STATE BOARD OF CONTROL}

E. B. STEPHENSON, President_-_-_-_-_-_-_-_-_-_--Charleston, W. Va. JAMES S. LAKIN -_-_-_-_-_-_-_-_-_-_-_Charleston, W. Va. J. M. WILLIAMSON_-_-_-_-_-_-_-_Charleston, W. Va.

The State Board of Control has the direction of the financial and business affairs of the state educational institutions.

\section{THE STATE BOARD OF EDUCATION}

M. P. SHAWKEY, President_---_---_Charleston, W. Va. State Superintendent of Schools

GEORGE S. LAIDLEY

Charleston, W. Va. NOAH G. KEIM Elkins, W. Va.

EARL W. OGLEBAY Wheeling, W. Va.

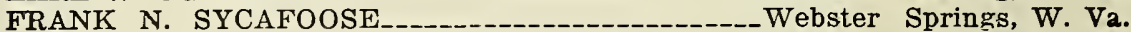
L. W. BURNS

W. C. COOK Grafton, W. Va. scholastic nature concerning the state educational institutions.

\section{WEST VIRGINIA UNIVERSITY}

FRANK BUTLER TROTTER, LL.D.

President

\section{Agricultural Experiment Station Staff}

JOHN LEE COULTER, A.M., Ph.D.

BERT H. HITE, M.S.

FRANK B. KUNST, A.B.

CHARLES E. WEAKLEY, Jr.

J. H. BERGHIUS-KRAK, B.Sc

W. E. RUMSEY, B.S.Agr.

N. J. GIDDINGS, Ph.D.

ANTHONY BERG, B.S.

ERNEST L. ANTHONY, M.S.

H. O. HENDERSON, M.S.

HORACE ATWOOD, M.S.Agr.

E. L. ANDREWS, B.S.Agr.

ROBERT M. SALTER, M.SC.

R. E. STEPHENSON, M.S.

I. \$. COOK, Ir., B.S.Agr.

T. C. McILVANE, M.S.Agr.

Welch, W. Va.

G. L. SCHUSTER, M.Sc

J. K. SHAW, Ph.D.

H. A. JONES, Ph.D.

L. F. SUTTON, B.S., B.S.Agr.

H. E. KNOWLTON, B.S.Agr.

H. L. CRANE, M.S.Agr.

ROLAND H. PATCH, M.S.

ERNEST ANGELO, B.S.Agr.

L. M. PEAIRS, M.S.

E. A. LIVESAY, M.S.Agr

Vice-Director and Chemist

J. J. YOKE, B.S.Agr. Assistant Chemist Assistant Chemist Assistant Chemist State Entomologist Pairyman - Assistant Dairyman - Assistant Dairyman Assistant Soil Investigations Resea rch Asronomist Assistant Agronomist Assistant Agronomist *R. H. TUCKWILLER, B.S.Ag

C. V. WILSON, B.S.Agr.

A. J. DADISMÁN, M.S.Agr.

Assistant Horticulturist ${ }^{*}$ C. F. SARLE, B.S.Agr.

C. A. LUEDER, D.V.M.

c. E. STOCKDALE, B.S.Agr. Assistant Horticulturist Assistant Horticulturist Assistant Horticulturist -Assistant Horticulturist Assistant Hortleulturist -Assistant Horticulturist D. M. WILLIS, LL.M. J. C. JOHNSTON MART A. FOX

Research Entomologist Animal Husbandry Assistant in Animal Husbandry Assistant in Animal Husbandry Assistant in Animal Husbandry in Farm Economics Assistant in Farm Economics AgriculturaI Editor Financial Secretary Chief Clerk

- In co-operation with U. S. Dept. of Agriculture.

**Resigned September, 1919. Assistant Librarian 


\section{S U M M A R Y}

The data for this study were obtained from farm survey records from 260 farms for two consecutive years; 239 of the farms were operated by owners and 21 by tenants. The farms operated by owners were classified according to type: 98 beef farms, 121 general farms, and 20 daicy farms .

Averaging the two years, the 98 beef farms contained 396 acres, made a family income of $\$ 1590$ and a labor income of $\$ 94$. The 121 general farms contained 158 acres, made a family income of $\$ 532$ and a labor income of (minus) $-\$ 60$. The 20 dairy farms contained 156 acres, made a family income of $\$ 1268$ and a labor income of $\$ 366$. (See page 14.)

The size of farm business was the most important factor influencing farm earnings. About 100 head of beef cattle per farm seemed to be the smallest profitable unit for beef production. The beef farms that had the largest number of cattle units per farm made the best use of crop and pasture land, the best use of labor, and had the largest proportion of their total capital invested in working capital. The beef farms that had the smallest amount of crop and pasture land to the animal unit were the most profitable. The farm business of the smaller beef farms and the general farms seemed to be too small to be very profitable.

The average farm in the region surveyed returned about five per cent interest on the capital invested, and but little in addition as a return for the labor and supervision of the operator.

Conditions are ideal for dairying except that markets for large quantities of milk are unsteady or lacking. 


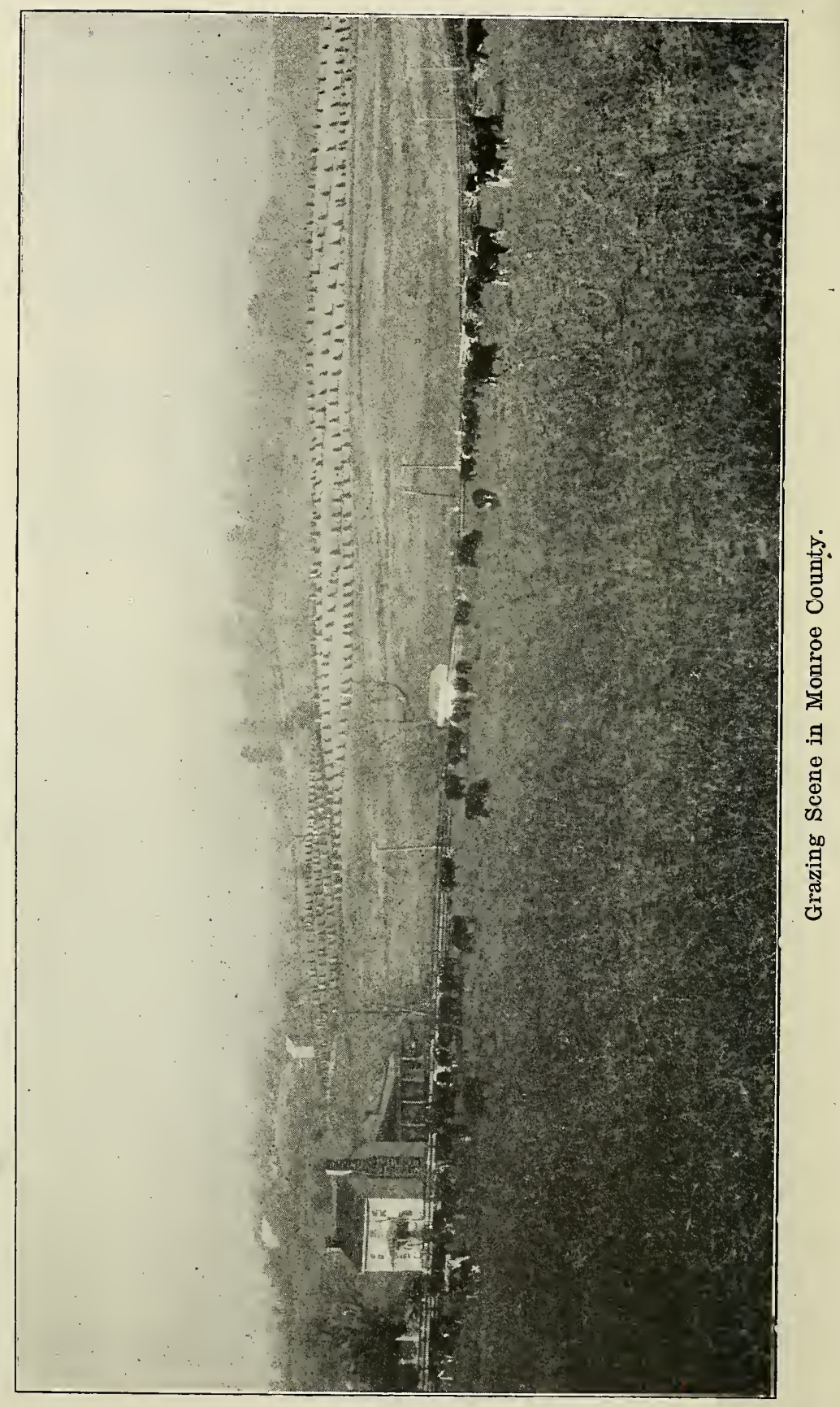




\title{
A TWO - YEAR FARM MANAGEMENT SURVEY OF GREENBRIER AND MONROE COUNTIES
}

\author{
BY A. J. DADISMAN and C. F. SARLE
}

\section{CONTENTS}

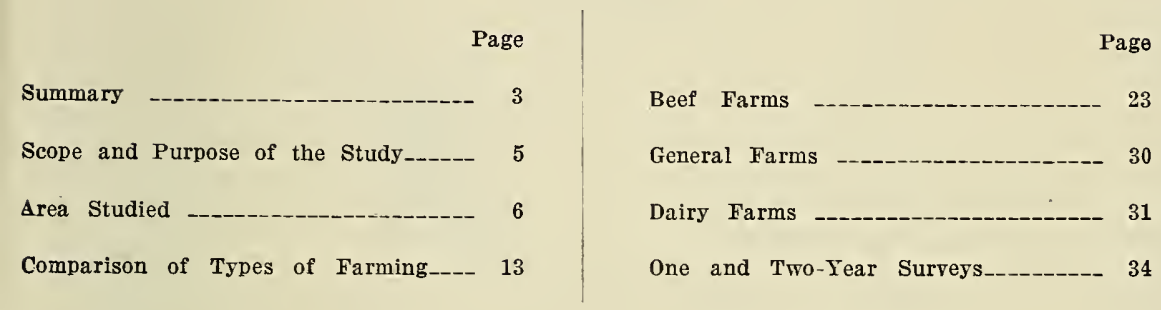

\section{SCOPE AND PURPOSE OF THE STUDY}

This bulletin presents a study of a farm management survey of ¿60 farms for two consecutive years, $1914-15$ and $1915-16$, or 520 records in all. These farms are located in Greenbrier and Monroe counties in the southeastern part of West Virginia. The region covered by this survey probably represents the largest area of blue grass land in the State where agriculture is the leading and practically the only industry. The results of this study, though strictly applicable only to the area surveyed, offer valuable suggestions to farmers in other secrions where the production of beef cattle is a leading farm enterprise.

The purposes in conducting this investigation were in part: (1) to obtain a knowledge of the farm management practices followed in a typical blue grass area where agriculture is the leading industry; (2) to determine the important factors that influence the profitableness of farming in this region; (3) to suggest ways of improving the organization and management of the less successful farms of the reregion; and (4) to compare the relative merits of a one-year survey with one taken for two consecutive years. 


\section{AREA STUDIED}

Greenbrier and Monroe counties are in the southeastern part of West Virginia, and border on Virginia.

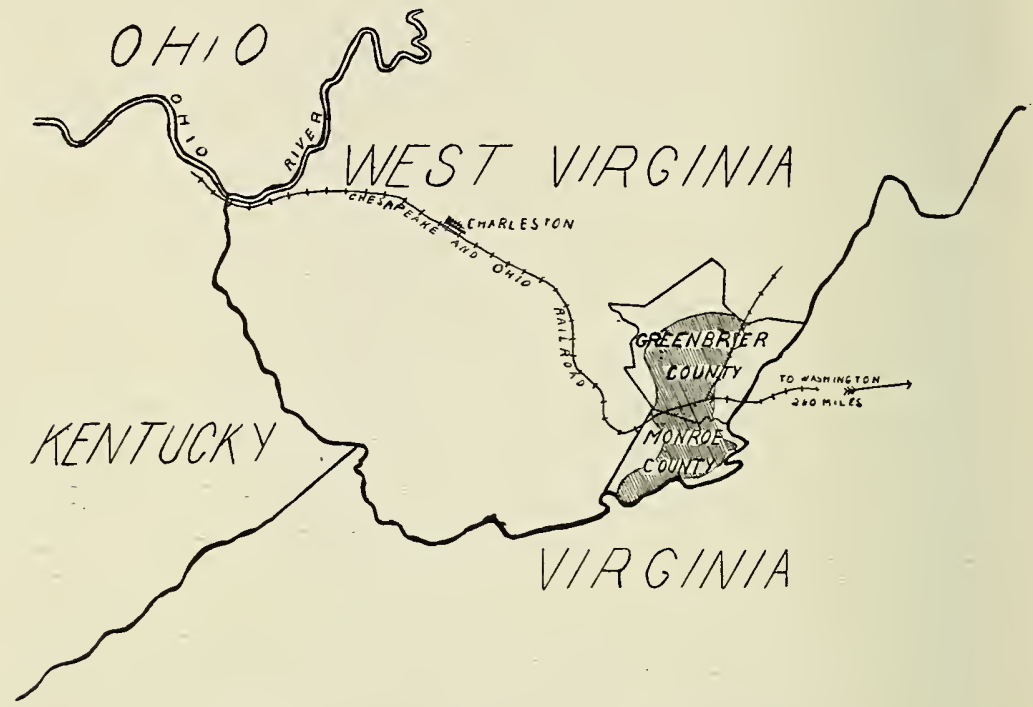

Map Showing Location of Area Studied.

Topography and Soils.-The agricultural area of this section is largely a broad, rolling plateau, extending from north to south through these two counties. This plateau has a general elevation of about 2200 feet. The larger streams have cut deep narrow valleys in this plateau, which is surrounded by high mountain ridges. To the east and north, these ridges attain a height of four thousand feet. The Allegheny mountains extend through the eastern part of both counties. The Greenbrier river, a branch of the Great Kanawha, drains a large part of this section.

The land is largely underlain with limestone. In the eastern and central parts, the soils are predominantly of limestone origin and, while not yet surveyed, probably belong to the Hagerstown, Frankstown, and Frederick series. They are mainly clays and clay loams. In the western part of the area the soils are of non-limestone origin and probably belong to the Upshur, Dekalb, and Pope series, varying from sandy loams to clays.

Climate.-The climate is pleasant and healthful. 
February, 1920] TWO - YEAR FARM MANAGEMENT SURVEY

TABLE 1.-Rainfall in Area Studied.*

\begin{tabular}{|c|c|c|c|c|c|c|c|}
\hline Year & Jan. & Feb. & Mar. & Apr. & May & June & \\
\hline 1914 & 3.96 & 4.71 & 3.55 & 3.70 & .96 & 1.44 & \\
\hline 1915 & 4.44 & 2.94 & .84 & 2.13 & 2.88 & 4.07 & \\
\hline $\begin{array}{l}\text { Normal } \\
\quad \text { Rainfall_-_- }\end{array}$ & 3.29 & 2.91 & 3.98 & 3.18 & 3.73 & 4.12 & \\
\hline Year & July & Aug. & Sept. & Oct. & Nov. & Dec. & Total \\
\hline 1914 & 4.74 & 3.26 & 1.49 & 3.57 & .99 & 5.30 & 37.67 \\
\hline 1915 & 3.95 & 3.65 & 4.01 & 4.66 & 2.17 & 2.92 & 38.66 \\
\hline $\begin{array}{l}\text { Normal } \\
\quad \text { Rainfall_-- }\end{array}$ & 3.83 & 3.50 & 2.75 & 2.64 & 2.27 & 2.78 & $\therefore \quad 38.98$ \\
\hline
\end{tabular}

*Climatological report, United States Department of Agriculture Weather Bureau, Lewisburg, W. Va.

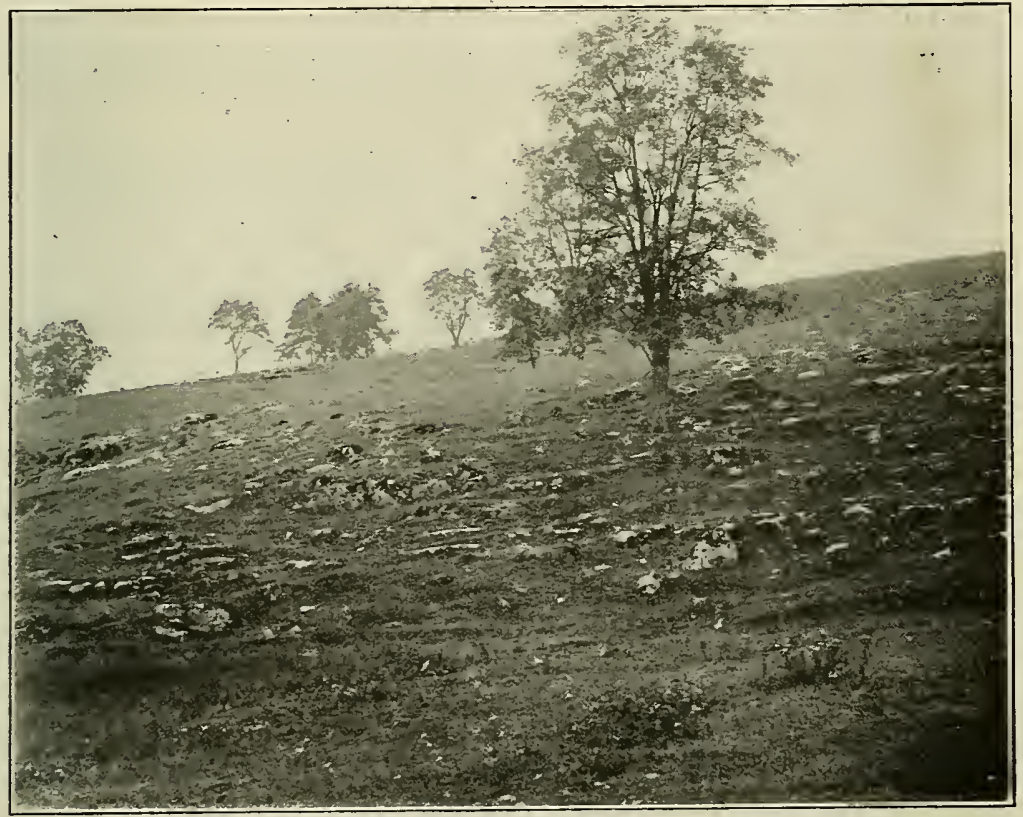

Typical Bluegrass Pasture Showing Outcropping Limestone. 
Table 1 shows the rainfall by months for the two years of the survey and also the normal rainfall. The normal rainfall is about 39 inches annually, of which 18 inches fall between April 1 and September 1. In 1914 the annual rainfall was one inch below normal and during the five months, April 1 to September 1, it was four inches below normal; the months of May and June together had less than $21 / 2$ inches of rainfall as compared with practically 7 inches in 1915 . In 1915 the annual rainfall was nearly normal with 17 inches falling from April 1 to September 1.

The last killing frost in the spring may be expected from the 15th of April to the 29th of May. The first killing frost in autumn may be expected from September 14 to October 24. The chances are a little better than three to one that frost injury will not occur after May 15, and nearly the same that the first killing frost will not come before October 1.

The growing season of 135 days in 1914 was 15 days shorter than the normal period, which is 150 days. The growing season of 175 days in 1915 was exceptionally long, being 25 days longer than normal, and the longest in 16 years.

The annual mean temperature is about 51 degrees, with the lowest monthly mean of 31 degrees, in January, and the highest of 72 degrees, in July. The prevailing wind comes from the west.

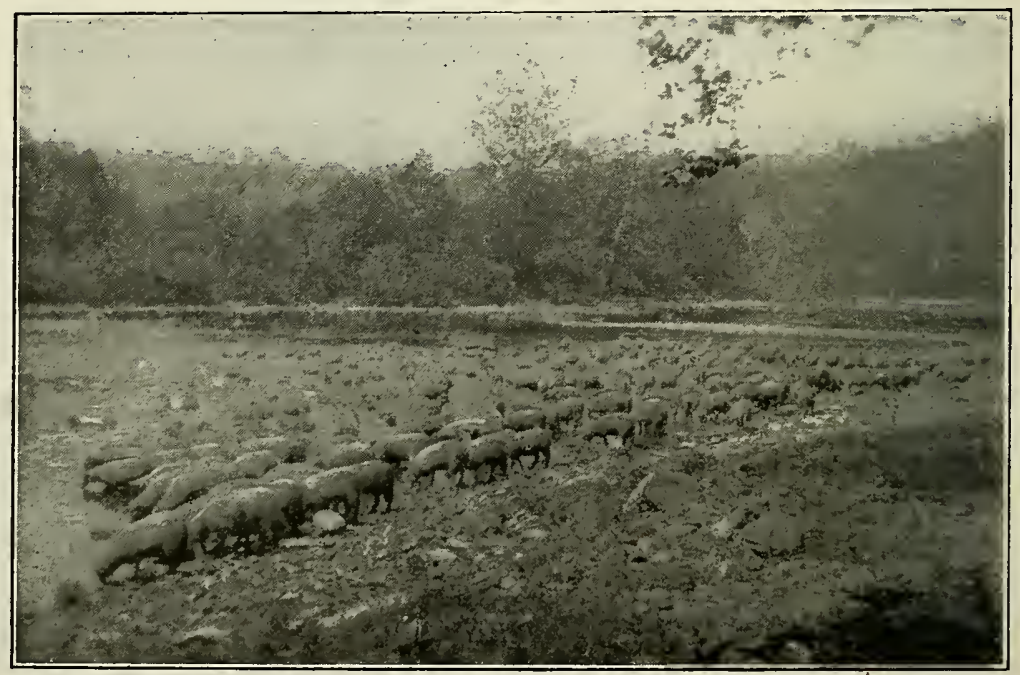

A Profitable Method of Marketing Bluegrass. 
Markets and Roads.-The Chesapeake and Ohio Railroad passes through the central part of this region. Washington is 260 miles, and Baltimore 300 miles east. Charleston, the capital of West Virginia, with a population of 35,000 in 1915 , is 125 miles west. There is a branch railroad extending northward through Greenbrier County.

The beef cattle of this area are usually shipped to the Baltimore markets. Some poultry products and cream are shipped to Washington. White Sulphur Springs, a large summer resort, is a potential market for farm produce. The markets of the large coal fields to the westward have not been utilized to any appreciable extent by the farmers of this section. Some ice cream was made near Lewisburg and there were a few creameries making a small amount of butter during a part of the year when this survey was made.

There were but a few miles of improved roads in the two counties. The dirt roads were excellent in summer, but almost impassible in many places in winter. Some improved roads were in process of construction.

Labor.-A large part of the farm work was performed by the operators and their families. There were very few colored laborers in this section. Farm labor was not plentiful, even though this section is somewhat remote from industrial regions. In the more mountainous parts of the area there was still a considerable amount of timber. Some men living on farms were working part time in the woods. A considerable quantity of tan bark and pulp wood was shipped out. A few saw mills were still operating. Many laborers preferred to work in the woods rather than on farms, because the work lasted throughout the whole year.

Agricultural History.-In 1850, the population of Monroe County was a little more than 10,000 , and that of Greenbrier was about the same. In 1910, Monroe had a population of about 13,000 and Greenbrier nearly 25,000 , making a total for the region of 38,000 people.

There have been several changes in the production of crops during this period. Of the cereals, corn and wheat have steadily increased until they have about doubled in production. The production of oats has gradually decreased and very little rye has been produced in the last forty years. Hay has constantly increased throughout the whole period, and the production in 1910 was three times that in 1850 . Po- 
tato production shows a constant increase from about fourteen thousand bushels in 1850 to more than a hundred and twenty thousand in 1910. Considerable tobacco was produced in Monroe County from 1860 to $18 \% 0$, but the last census shows almost none. Practically no tobacco has been grown in Greenbrier County.

From 1850 to 1910 , the number of dairy cattle gradually increased. The number of other cattle varied up to 1890 , but since then has shown a slight decrease. The number of sheep varied greatly during the period, but showed a marked increase from 1900 to 1910 . Horses steadily increased in numbers during the period.

In 1880 there were 2754 farms in the two counties; in 1910 they had increased to 4469 . The average size of farms in 1880 was 323 acres in Greenbrier County and 192 acres in Monroe. In 1910 the average size had decreased until it was about the same in both counties, or 130 acres in Greenbrier , and 126 acres in Monroe.

Crops.-In Greenbrier and Monroe counties, most farmers own their farms and practice general farming, with considerable livestock

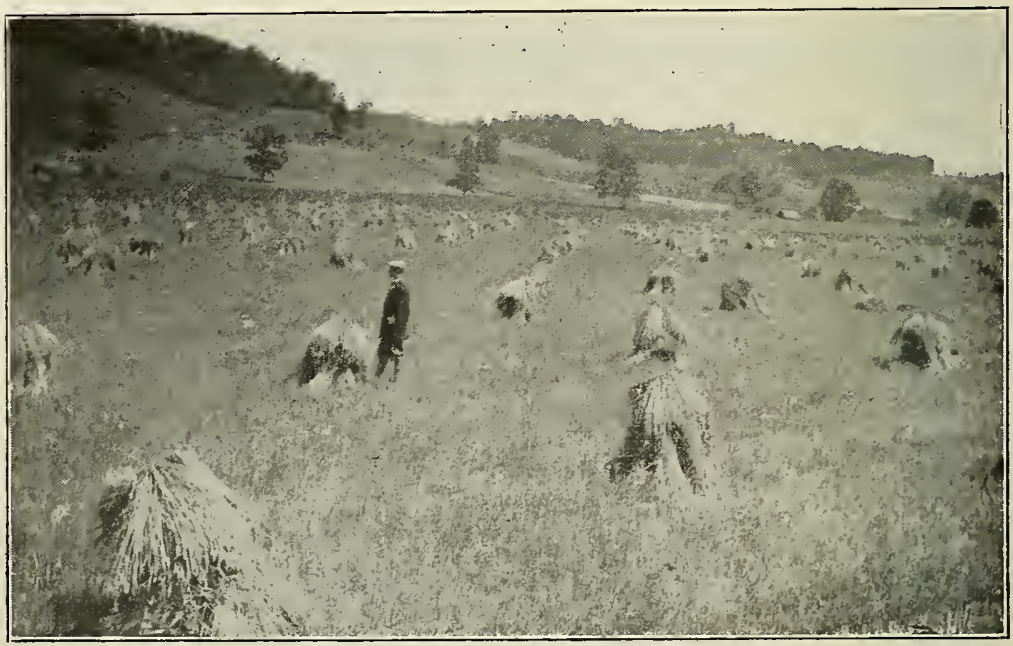

The Cash Crop in the Bluegràss Area.

production. Most of the feed for livestock is grown on the farms. Corn, wheat, and hay were the most important crops on the farms studied in this survey. Corn, including that for grain and for silage, 
in yield for the two years. Hay yielded nearly one-half of a ton more per acre the second year than the first; oats, 24.3 bushels more and buckwheat 4.8 bushels more. All the crops, except hay, showed a larger acreage harvested in 1915 than in 1914 . Corn for silage showed a greater increase in acreage than any other crop. Forty-six farmers reported corn for silage in 1914, and seventy-one in 1915.

Livestock.-The growing and fattening of beef cattle is the most important livestock enterprise in this region. The farms in the rougher sections of these counties and in the neighboring counties are drawn upon by large farmers, having bluegrass pasture, for calves, yearlings, and some older livestock. The cattle are matured on the nutritious bluegrass pasture for which this region is famous. The farmers have organized a purebred Shorthorn Breeders' Association. There were also some breeders of purebred Herefords, and a few dairy herds mostly grade Jerseys, Guernseys, and Holsteins were found near the shipping points. Nearly all the farmers had two or more cows to

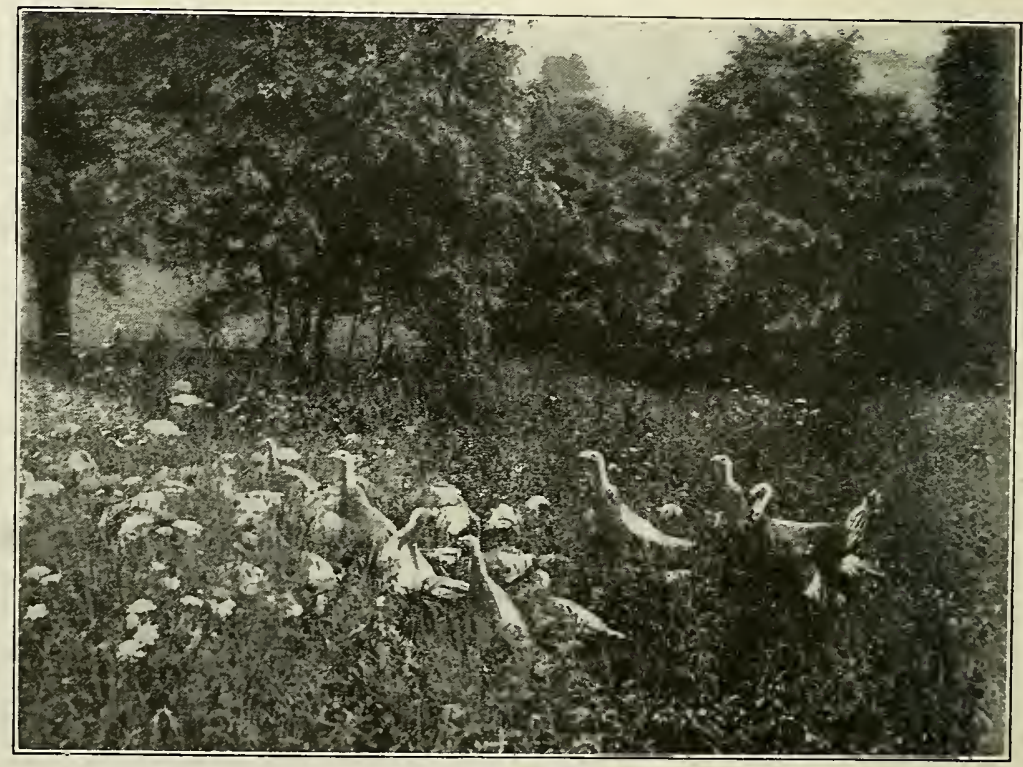

Turkey Raising, A Profitable Industry on Many of the Farms. 
supply the family with milk and butter. Coarse wool sheep were found in many of the farms. Sheep are well adapted, not only to the rougher and more mountainous parts of this region, but they also have a place on nearly every farm.

In addition to the farm flock of hens, turkey raising was an important enterprise on many of the farms. Hogs were produced mostly for home use. A few dairy farms, selling cream, kept the hogs to utilize skim milk. Before the automobile became popular the breeding and raising of saddle and trotting horses was an important enterprise on many farms.

Land Tenure.-There were comparatively few tenant farms in the section covered by this survey. Of the 260 complete records for two years, there were seven farmers who did not own any of the land which they operated, while fourteen farmers share rented a considerable part of their crop land. Renting additional pasture land by the "boundary," rather than by the acre, was a common practice in the region. Little pasture was rented in any other way. In the study of these farms, this practice has been considered in the same way as if the farmer had purchased additional feed for his livestock. Ownerfarmers, as used in this study, includes those renting additional pasture in this way, and those share-renting a small part of their crop land one or both years. The few tenant farms from which records were taken compare favorably with the owner farms of a similar type and size.

\section{COMPARISON OF TYPES OF FARMING}

There was considerable difference of opinion among the farmers of these counties as to which was the best type of farming for the region, as well as for the individual farm. A study and comparison of the three important types of farming found here was made with the view of throwing some light upon this problem.

The 239 owner farms included in this study for two consecutive years were divided into three classes according to the type of farming followed. Ninety-eight of these were classed as beef farms. They consisted of farms on which 40 percent or more of the total receipts were derived from beef cattle. Twenty of the farms were classed as dairy farms, as 40 percent of their total receipts were from the dairy. On 
one hundred and twenty-one of the farms, less than 40 percent of the total receipts were from any one of these sources. These were classed as general farms, since their receipts were from both crops and livestock. In classifying these farms due allowance was made for yearly fluctuations in amount of receipts from the different farm enterprises.

It seems in this study of types of farming that the first year might be considered a normal year for the beef farms. The second year the pastures had been injured considerably by the drought of the previous year. The second year was probably the better year to study the general farms, as crop yields were abnormally low the first year. Neither year seemed to have been abnormal for the dairy farms.

Farm Earnings.- If farm expenses are subtracted from farm receipts the result is farm income. The farm income is made up of income from capital invested and from operator's labor and supervision. If the interest that the capital would have earned if invested in some other business be subtracted from the farm income there will be left the amount that the farmer should have for his year's labor and supervision. This amount is labor income. In addition to his labor income the farmer has the use of a dwelling, and receives that part of the family living furnished by the farm. If the value of the labor of the members of the family, other than the operator, is added to the farm income, the sum is family income. This latter is the amount that the farmer who owns his farm, free of debt, has for the support of his family, and for savings.

\section{TABLE 3.-Farm Earnings}

(239 Owner Farms 1914-15 and 1915-16

\begin{tabular}{|c|c|c|c|c|c|c|c|c|c|}
\hline \multirow{3}{*}{ Farm Receipts --- } & \multicolumn{3}{|c|}{98 BEEF FARMS } & \multicolumn{3}{|c|}{121 GENERAL FARMS } & \multicolumn{3}{|c|}{20 DAIRY FARMS } \\
\hline & | 1914-15 & $1915-16$ & $\begin{array}{l}\text { Arerage } \\
2 \text { Yrs. }\end{array}$ & $\mid 1914-15$ & $1915-16$ & $\begin{array}{l}\text { Average| } \\
2 \text { Yrs }\end{array}$ & $1914-15$ & $1915-16$ & $\begin{array}{l}\text { Average } \\
2 \text { Yrs. }\end{array}$ \\
\hline & $\$ 2605$ & $\$ 2543$ & $\$ 2574$ & $\$ 782$ & $\$ 1025$ & $\$ 904$ & $\$ 2089$ & $\$ 2251$ & $\$ 2170$ \\
\hline Farm Expenses - & 1086 & 1144 & 1115 & 456 & 469 & 462 & 1034 & 1003 & 1018 \\
\hline $\begin{array}{l}\text { Farm Income } \\
\text { Interest on }\end{array}$ & 1519 & 1399 & 1459 & 326 & 556 & 441 & 1055 & 1248 & 1152 \\
\hline Capital at $5 \%$ & 1358 & 1372 & 1365 & 499 & 5,04 & 502 & 785 & 787 & 786 \\
\hline $\begin{array}{l}\text { Sabor Income } \\
\text { Value of }\end{array}$ & 161 & 27 & 94 & -173 & 52 & -60 & 270 & 461 & 366 \\
\hline Family Labor & 127 & 135 & 131 & 88 & 95 & 92 & 117 & 115 & 116 \\
\hline 'amily Income -- & 1646 & 1534 & 1590 & 414 & 651 & 532 & 1172 & 1363 & 1268 \\
\hline
\end{tabular}


Table 3 shows the farm earnings on the three types of farms for the two years. The beef farms made the largest family income, which is the important factor to consider where most of the farms are owned and largely paid for. The 98 beef farms averaged $\$ 1,590$ family income; the 121 general farms, $\$ 532$; and the 20 dairy farms, $\$ 1,268$. The beef farms earned nearly $\$ 100$ more than five percent interest on investment, and the general farms made a little less than five percent interest on investment for the two years; while the 20 dairy farms made five percent interest on investment and fair wages in addition.

Returns on the beef farms were less the second year than the first. The second year was a better crop year, but livestock did not bring as high prices in the fall as had been previously expected. A number of beef farmers lost a considerable amount of money buying livestock the spring and fall before at a higher price than the final selling price warranted.

The general farms showed better returns the second year than the first. The first year was a poor crop year and the second a reasonably good one. Since the growing of crops was the most important phase of their farming, there was a larger surplus of crops to sell the second year. The dairy farmers were able to increase their labor incomes the second year, largely because of an increase in size of business and better crop yields.

Size of Farm Business.-There are several ways of measuring the size of a farm business. The total number of acres in the farm is in itself not a satisfactory measure for the farms in this region, because a large number of the farmers cash rent additional pasture land by the "boundary" rather than by the acre, and there is a considerable amount of rough waste land on many farms. The number of crop acres is not a satisfactory measure of size, as bluegrass, one of the most important crops of the section, is not included. If the sum of the crop acres and the pasture area owned is used, it should include also the cash rented pasture. It is difficult to find a common measure of size of business where farming varies as much as it does in this region. The actual amount of man labor on crops and livestock per farm is probably the best measure of size of business that can be used to compare all three types of farms. 


\section{TABLE 4.--Size of Farm Business}

(239 Owner Farms 1914-15 and 1915-16)

\begin{tabular}{|c|c|c|c|c|c|c|c|c|c|}
\hline \multirow[b]{2}{*}{ Measure of Size } & \multicolumn{3}{|c|}{98 BEEF FARMS } & \multicolumn{3}{|c|}{121 GENERAL FARMS } & \multicolumn{3}{|c|}{20 DAIBY FARMS } \\
\hline & $\mid 1914-15$ & 1915-16 & $\mid \begin{array}{cc}\text { Average } \\
2 \text { Yrs. }\end{array}$ & |1914-15 & $1915-1 \epsilon$ & $\begin{array}{c}\text { Arerage } \\
2 \text { Yrs }\end{array}$ & |1914-15 & 1915-16 & $\begin{array}{l}\text { Average } \\
2 \text { Yrs. }\end{array}$ \\
\hline $\begin{array}{l}\text { Average Acres } \\
\text { per Farm } \\
\text { Value of Pasture }\end{array}$ & 397 & 394 & 396 & 156 & 159 & 158 & 156 & 155 & 156 \\
\hline Rented & $\$ 79$ & $\$ 98$ & $\$ 88$ & $\$ 7$ & $\$ 5$ & $\$ 6$ & $\$ 46$ & $\$ 48$ & $\$ 47$ \\
\hline Acres in Crops & 79 & 77 & 78 & 41 & 42 & 42 & 46 & 49 & 48 \\
\hline $\begin{array}{l}\text { Productive Animal } \\
\text { Units }\end{array}$ & 64 & 64 & 64 & 15 & 16 & 16 & 27 & 28 & 28 \\
\hline $\begin{array}{l}\text { Man Days on Crops } \\
\text { and Livestock }\end{array}$ & 420 & 434 & 427 & 214 & 235 & 224 & 474 & 514 & 494 \\
\hline $\begin{array}{l}\text { Horse Days on } \\
\text { Crops and } \\
\text { Livestock }\end{array}$ & 230 & 242 & 236 & 128 & 141 & 134 & 202 & 208 & 205 \\
\hline
\end{tabular}

Table 4 shows the three types of farms compared on the basis of the size of farm business using various measures of size. The beef farms had the largest acreage, the largest number of crop acres, and the largest number of productive animal units. An animal unit is a mature horse or cow or a number of other livestock which eat about the same amount as a horse or a cow. The dairy farms had the largest number of man days work per farn. The general farms were the smallest with respect to all the measures used except acres per farm.

Production.-The average yields of the various crops were discussed on page 11. A number used for comparing the yields of crops grown on a given farm with the average of the region represented as 100 , is known as the crop index. The amount of income per productive animal unit is used as a comparative measure for the production of the livestock.

TABLE 5.-Crop Yields and Returns from Livestock (239 Owner Farms 1914-15 and 1915-16).

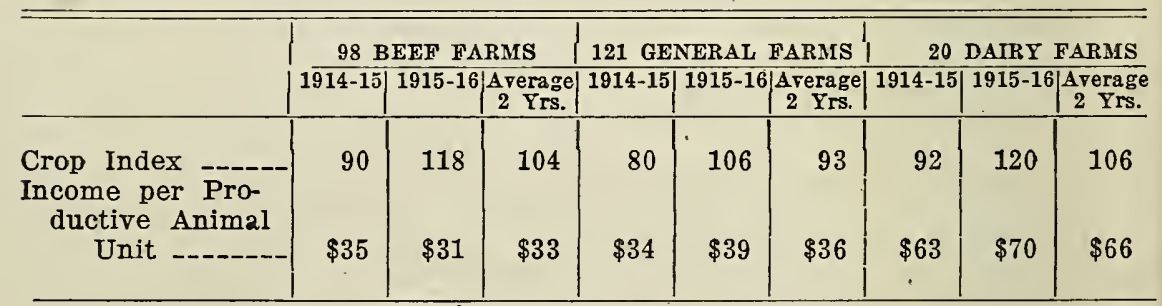


Table 5 shows the comparative returns from crops and from livestock on the three types of farms. The crop yields had about the same general increase the second year on all of the farms. The crop yields on the beef farms and dairy farms were nearly the same for both years. More fertilizer was purchased per crop acre on the dairy farms than on the other two types. The beef farms had 1.1 acres of crops per animal unit, the dairy farms 1.5 acres and the general farms 2.2 acres. Crop yields on the general farms were considerably lower for both years than on the livestock farms.

The dairy farms had nearly twice the income per productive animal unit as had the beef or general farms. Taking the region as a whole, one animal unit of poultry, 100 hens or 25 turkeys, showed the highest income per animal unit, averaging more than $\$ 110$. The dairy cow returned about $\$ 75$ for dairy products. The income per animal unit of sheep, 7 sheep used as an animal unit, averaged $\$ 5$ more than the income per animal unit of beef cattle. Although the beef farms had nearly twice the number of sheep per farm as the general farms and about one-third more poultry, the proportion of the total number of animal units in these more productive forms of livestock was much larger on the general farms.

Utilization of Labor.-The full utilization of labor on the farm is important. The following table compares the utilization of labor on the three types of farms.

TABLE 6.-Utilization of Labor

(239 Owner Farms 1914-15 and 1915-16)

\begin{tabular}{|c|c|c|c|c|c|c|c|c|c|}
\hline & \multicolumn{3}{|c|}{98 BEEF FARMS } & \multirow{2}{*}{\multicolumn{2}{|c|}{$\begin{array}{l}\text { 121 GENERAL } \\
|1914-15| 1915-16\end{array}$}} & FARMS & \multirow{2}{*}{$\frac{20}{1914-15}$} & \multirow{2}{*}{$\begin{array}{l}\text { DAIRY } \\
1915-16 \\
\end{array}$} & \multirow{2}{*}{$\begin{array}{l}\text { FARMS } \\
3 \text { Average } \\
\text { | } 2 \text { Yrs. }\end{array}$} \\
\hline & $1914-15$ & $1915-16$ & $\begin{array}{l}\text { Average } \\
2 \text { Yrs. }\end{array}$ & & & $\begin{array}{c}\text { Average } \\
2 \text { Yrs. }\end{array}$ & & & \\
\hline $\begin{array}{l}\text { Crop Acres } \\
\text { per Man }\end{array}$ & 30 & 30 & 30 & 24 & 25 & 24 & 22 & 22 & 22 \\
\hline $\begin{array}{l}\text { Crop Acres } \\
\text { per Horse }\end{array}$ & 13 & 13 & 13 & 12 & 12 & 12 & 12 & 12 & 12 \\
\hline $\begin{array}{l}\text { Productive Animal } \\
\text { Units per Man-- }\end{array}$ & 24 & 24 & 24 & 9 & 9 & 9 & 13 & 13 & 13 \\
\hline $\begin{array}{l}\text { Productive Animal } \\
\text { Units per Horse }\end{array}$ & 10 & 11 & 10 & 4 & 5 & 4 & 7 & 7 & 7 \\
\hline $\begin{array}{l}\text { Man Day's Work } \\
\text { per Man on Crops } \\
\text { and Livestock }\end{array}$ & 162 & 167 & 164 & 126 & 138 & 132 & 226 & 243 & 234 \\
\hline $\begin{array}{l}\text { Horse Day's Work } \\
\text { per Horse on } \\
\text { Crops and Live- } \\
\text { stock }\end{array}$ & 38 & 40 & 39 & 38 & 40 & 39 & 50 & 52 & 51 \\
\hline
\end{tabular}


In the number of acres of crops per man the beef farms stood first, the general farms second, and the dairy farms last. The beef farms had more productive animal units per man than the other types while the dairy farms were second. The dairy farms showed more than 40 percent better utilization of man labor than the beef farms and more than 75 percent better utilization than the general farms. The amount of man labor per man was very low on the general and beef farms and rather low on the dairy farms.

One horse cared for about the same acreage of crops on all three types. The dairy farms showed more than 30 percent better utilization of horse labor than either of the other two types. The amount of horse labor per horse on crops and livestock was low on all three types. Even on the dairy farms where horse labor was used to the best advantage, a horse worked only 51 days out of the year, or an average of 1.7 hours per day, while on the beef and general farms a horse averaged to work only 1.3 hours.

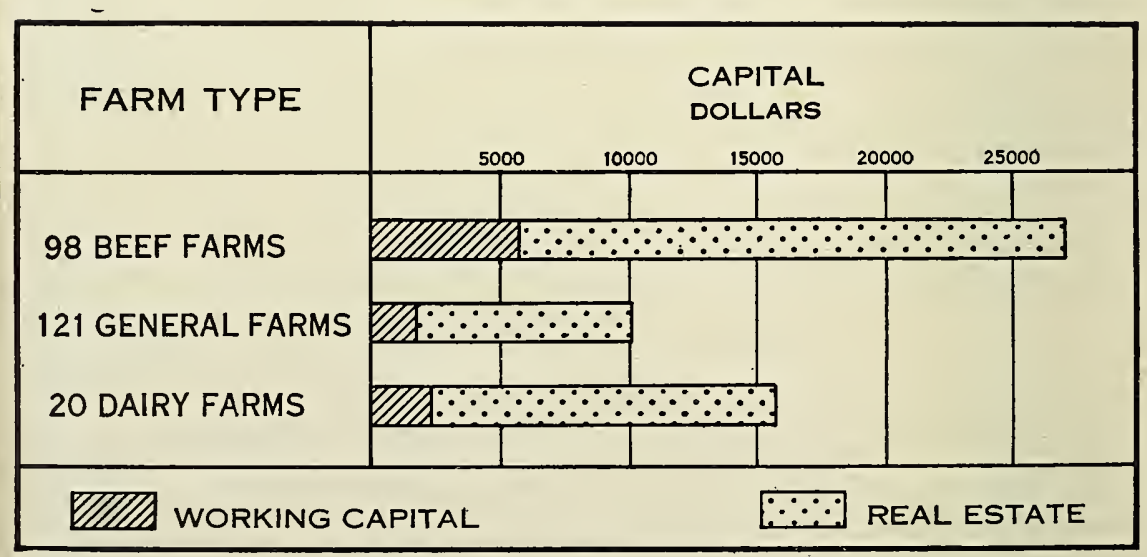

Average Amount and Distribution of Capital on the Three Types of Farms for Two Years, 1914-15 and 1915-16. 
Investment.-Capital is made up of fixed capital and working capital. Fixed capital is that invested in land, buildings and relatively permanent improvements, such as fences and tile drains. Working capital is that invested in livestock, farm machinery, feed and supplies, and cash to run the farm.

TABLE 7.-Amount and Distribution of Investment (239 Owner Farms 1914-15 and 1915-16).

\begin{tabular}{|c|c|c|c|c|c|c|}
\hline & | 98 Beef & f Farms I & 121 Gene & ral Farms & \$ 20 Dair & ry Farms \\
\hline & $\begin{array}{l}\text { Average } \\
\text { | Capital }\end{array}$ & \begin{tabular}{|} 
Percent \\
of Total \\
$\mid$ Capital
\end{tabular} & \begin{tabular}{|} 
Average \\
Capital
\end{tabular} & \begin{tabular}{|} 
Percent \\
lof Total \\
Capital|
\end{tabular} & $\begin{array}{l}\text { Average } \\
\text { Capital }\end{array}$ & $\mid \begin{array}{l}\text { Percent } \\
\text { of Total } \\
\text { Capital }\end{array}$ \\
\hline 1914-15 & & & & & & \\
\hline Total Capital & $\mid \$ 27147$ & 100.0 & $\$ 9985$ & 100.0 & $\$ 15694$ & 100.0 \\
\hline Fixed Capital & 21563 & 79.4 & 8392 & 84. & 12842 & 81.9 \\
\hline Dwellings & 1769 & 6.5 & 984 & 10. & 1582 & 10.1 \\
\hline Other Buildings & 986 & 3.6 & 443 & 4.4 & 922 & 5.9 \\
\hline Working Capital & 5584 & 20.6 & 1593 & 16. & 2852 & 18.1 \\
\hline Livestock & 4914 & 18.1 & 1288 & 12.9 & 2183 & 13.9 \\
\hline Machinery & 427 & 1.6 & 214 & 2.1 & 506 & 3.2 \\
\hline Feed and Supplies, and Cash & & & & & & \\
\hline to Run Farm & 243 & .9 & 91 & .9 & 163 & 1.0 \\
\hline $1915-16$ & & & & & & \\
\hline Total Capital & $\$ 27442$ & 100.0 & $\$ 10087$ & 100.0 & $\$ 15734$ & 100.0 \\
\hline Fixed Capital & 21469 & 78.2 & 8407 & 83.3 & 12722 & 80.9 \\
\hline Dwelling & 1790 & 6.5 & 985 & 9.8 & 1607 & 10.2 \\
\hline Other Buildings & 1281 & 4.7 & 498 & 4.9 & 1003 & 6.4 \\
\hline Working Capital & 5973 & 21.8 & 1680 & 16.7 & 3012 & 19.1 \\
\hline Livestock - & 5199 & 19.0 & 1377 & 13.7 & 2328 & 14.8 \\
\hline Machinery -- & 435 & 1.6 & 211 & 2.1 & 564 & 3.6 \\
\hline Feed and Supplies, and Cash & & & & & & \\
\hline to Run Farm & 339 & 1.2 & 92 & .9 & 120 & .7 \\
\hline
\end{tabular}

Table 7 shows the amount of capital invested and its distribution on the three types of farms. The beef farms had nearly three times as much capital as the general farms and twice as much as the dairy farms.

The beef farms had about twice as much working capital as the dairy farms and nearly four times that of the general farms. It was invested mostly in livestock. The general farms had less than half the amount of capital invested in machinery as did the beef farms and 
dairy farms, but it was a larger proportion of total capital than that of the beef farms. The general farms had the smallest amount of capital invested in feed, supplies, and cash to run the farm. The beef and dairy farms had dwellings and other buildings of nearly the same value, which was about twice the value of the dwellings and other buildings on the general farms. Although the buildings on the beef farms were the most valuable, they represented a smaller proportion of the total investment. The beef farms had a larger proportion of their investment in working capital than the general and dairy farms. The beef farms had the smallest proportion of capital invested in machinery; the dairy farms had the largest. The amount of capital invested in feed and supplies and cash to run the farm was relatively a small part of the total capital on all three types. The capital invested in livestock showed an increase during the two years, both in actual amount and in percent of total.

Value of Real Estate.-It is difficult to buy farm land in this region. Land values reach $\$ 150$ per acre, or even more for some of the best bluegrass land. The rough land helps to bring the general average down. The average value of real estate per acre was $\$ 5 \%$ for the beef farms, $\$ 59$ for the general farms, and $\$ 88$ for the dairy farms. From 1900 to 1910 , land in these two counties increased 90 percent in value.

Distance to Market.-Many of the farms included in this survey were from 10 to 15 miles from the nearest shipping point. The beef and general farms averaged about seven miles, and the dairy farms about half that distance from a shipping point.

Sources of Receipts.-The sources of receipts varied on the different types of farms and on the same farms in different years. 


\section{TABLE 8.-Sources of Receipts (239 Owner Farms 1914-15 and 1915-16)}

\begin{tabular}{|c|c|c|c|c|c|c|}
\hline & 98 Beef & Farms & $121 \mathrm{Gene}$ & eral Farms & 20 Dair & y Farms \\
\hline $\begin{array}{l}\text { Sources of } \\
\text { Receipts }\end{array}$ & Receipts/o & $\begin{array}{l}\text { Percent } \\
\text { f Total } \\
\text { eceipts }\end{array}$ & Receipts & $\left|\begin{array}{r}\text { Percent } \\
\text { of Total } \\
\text { Receipts }\end{array}\right|$ & Receipts & $\mid \begin{array}{l}\text { Percent } \\
\text { of Total } \\
\text { Receipts }\end{array}$ \\
\hline 1914-15 & $\$ 2605 \mid$ & 100. & $\$ 782$ & 100. & $\$ 2089$ & 100. \\
\hline $\begin{array}{l}\text { Receipts from: } \\
\text { Livestock }\end{array}$ & 2257 & 86.6 & 509 & 65.1 & 1671 & 80 . \\
\hline Livestock Products & 173 & 6.6 & 118 & 15.1 & 1101 & 52.7 \\
\hline Crops & 270 & 10.4 & 153 & 19.6 & 267 & 12.8 \\
\hline Increase in Feed and Supplies. & 6 & .2 & 5 & .6 & 1 & .0 \\
\hline Miscellaneous Sources & 72 & 2.8 & 115 & 14.7 & 150 & 7.2 \\
\hline $1915-16$ & & & & & & \\
\hline Total Receipts & $\$ 2543$ & 100. & $\$ 1025$ & 100. & $\$ 2251$ & 100. \\
\hline Receipts from: & & & & & & \\
\hline Livestock & 1983 & 78. & 414 & 40.4 & 1945 & 86.4 \\
\hline Livestock Products & 235 & 9.2 & 143 & 13.9 & 1334 & 59.4 \\
\hline Crops & 352 & 13.8 & 230 & 22.4 & 238 & 10.6 \\
\hline Increase in Feed and Supplies & 79 & 3.1 & 251 & 24.5 & 32 & 1.4 \\
\hline Miscellaneous Sources_-_ & 129 & 5.1 & 130 & 12.7 & 36 & 1.6 \\
\hline
\end{tabular}

Table 8 shows the sources of receipts on the three types of farms. The total receipts from livestock and its products were more than 80 percent of the total receipts on the beef farms and dairy farms. On the dairy farms 58 percent of the total receipts came from livestock products. On the general farms more than 50 percent of the total receipts came from livestock and livestock products. Some crops were sold on all three types of farms each year. Receipts from crops were relatively more important on the general farms than on the other types. There was practically no increase in the amount of feed and supplies during the first year, while the second year it was an important receipt on the general farms. Miscellaneous receipts, which include such items as labor off the farm, sale of lumber and posts, and land rental, were of little importance except on the general farms. Total receipts on the beef farms and dairy farms were more than twice the receipts on the general farms. The dairy and general farms showed a substantial increase in the amount of total receipts the second year, while the beef farms showed a small decrease.

Utilization of Pasture.-All three types of farms cash rented some additional pasture land by the "boundary." In addition to 3.7 acres of owned pasture land for each animal unit, the average beef farmer rented $\$ 1.20$ worth of additional pasture per animal unit. The dairy 


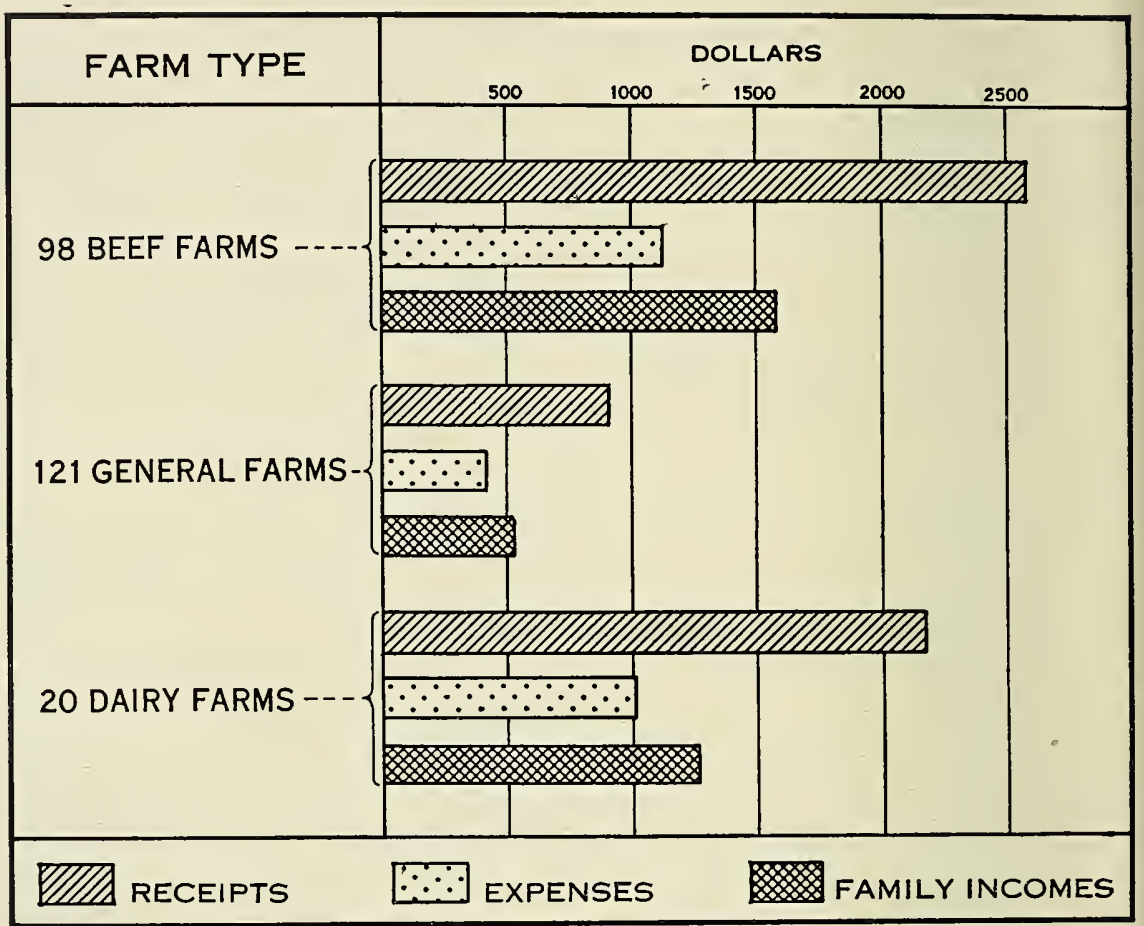

Average Receipts, Expenses, and Family Incomes on the Three Types of Farms for the Two Years, 1914-15 and 1915-16

farms had the smallest amount of owned pasture per animal unit, 2.4 acres, and the most pasture rented per animal unit, $\$ 1.50$. The general. farms had the most owned pasture per animal unit, 4.3 acres, and rented the least, 40 cents.

Age of Farmers.-The first year of the survey the dairy farmers averaged 42 years of age, which was 10 years younger than the beef farmers and 7 years younger than the general farmers. The younger men were engaged in the enterprises that were comparatively new to the region. 


\section{BEEF FARMS}

The first year of the survey, 1914-15, was more nearly typical of normal conditions on the beef farms than the second year. The low price of beef cattle in the fall of 1915 caused heavy losses to a number of beef cattle farmers who had purchased cattle at high prices the preceding spring and fall.

Size of Farm Business.-The number of cattle units per farm is perhaps the most satisfactory measure of size of farm business for the beef farms. The 98 beef farms ranged in size from 7 to more than 200 cattle units per farm, with an area of 70 to 1000 acres of owned land, and total capital of from $\$ 4000$ to more than $\$ 100,000$.

The 98 farms were divided first into two groups of 49 farms each on the basis of the number of cattle units per farm, the first group containing the farms with the smaller number of cattle units and the second the larger number. From these two groups the 20 farms with the smallest number of animal units per farm and the 20 with largest number were separated for the purpose of comparison.

TABLE 9.-Number of Cattle Units per Farm, Labor Income, Family Income, and Returns per Man Days Work on Crops and Livestock (98 Beef Farms 1914-15 and 1915-16).

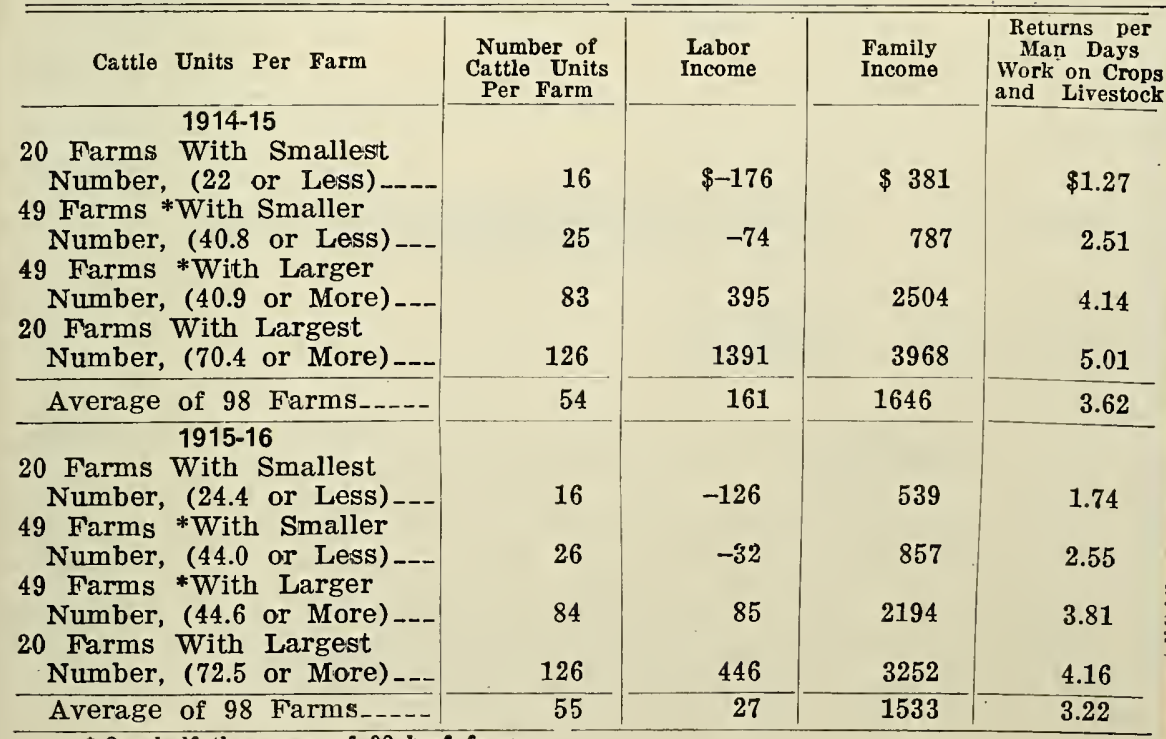

* One-half the group of 98 beef farms. 
The 20 farms with smaller number of animal units per farm the first year of the survey, averaged 16 cattle units per farm, had an average of 167 acres of owned land, 38 acres of which were in crops, and $\$ 9000$ total capital; while the 20 with largest number the same year, averaged 126 cattle units, had 654 acres of land, 133 acres in crops, and a total capital of nearly $\$ 46,000$. The beef farms had an average of 54 cattle units per farm.

Table 9 shows in a general way the relation of the number of cattle units per farm to labor income and family income. The 20 farms with the smallest number of cattle units per farm, an average of 16 , made a labor income of (minus) - $\$ 176$, while the 20 farms with the largest number of cattle units per farm, an average of 126 , made a labor in-

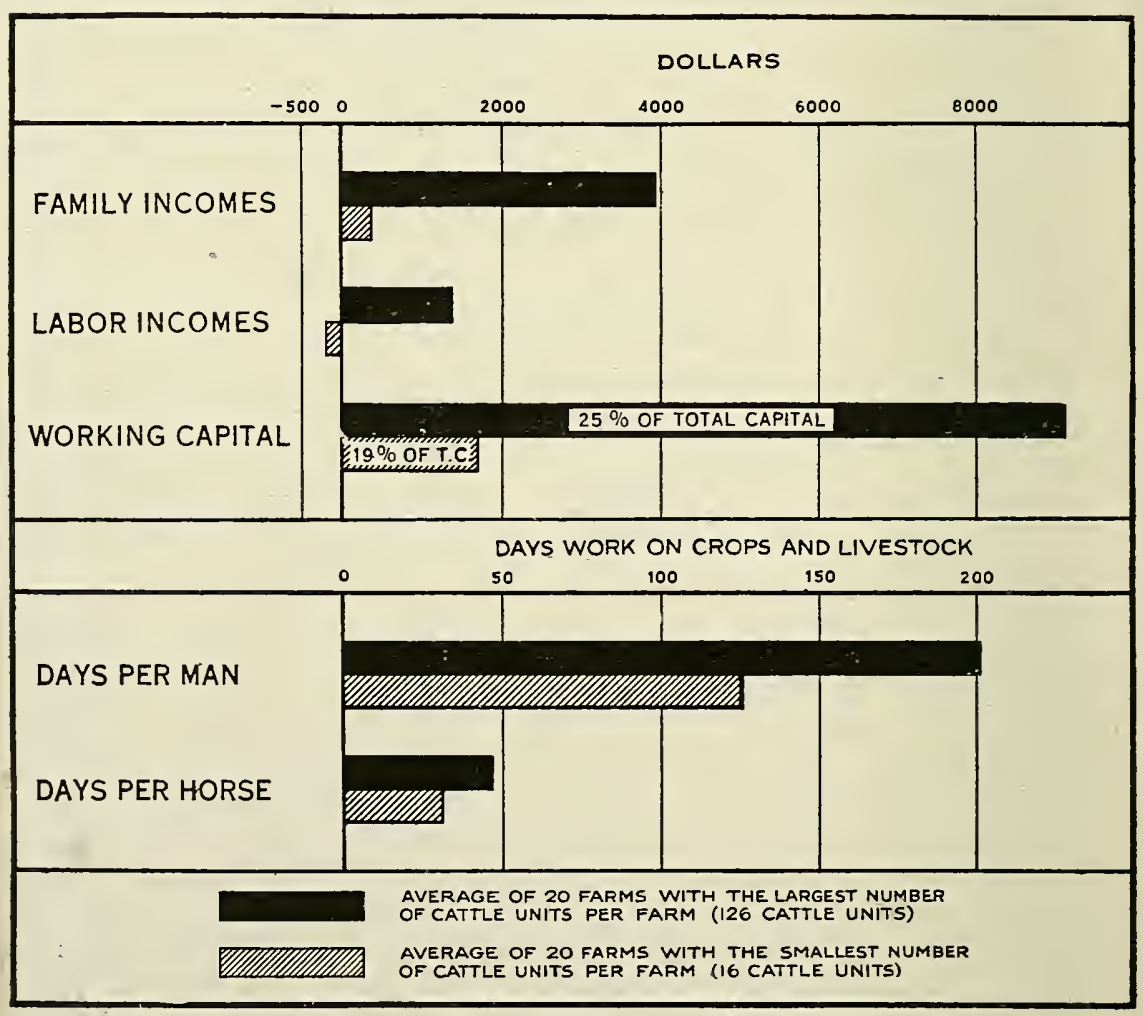

A Comparison of the 20 Farms With the Largest Number of Cattle Units per Farm with 20 Farms with the Smallest Number of Cattle Units per Farm as to Family Incomes, Labor Incomes, Working Capital, and Days Work per Man and Horse on Crops and Livestock for the Year 1914-15, Taken From Study of 98 Beef Farms. 
come of $\$ 1391$ the first year and $\$ 446$ the second year, or an average for the two years of $\$ 919$. The 98 beef farms were divided into two equal groups of 49 farms each on the basis of the number of cattle units per farm. The group of farms with the smaller number of cattle units per farm made a small minus labor income both years, while the group with the larger number of cattle units per farm made a labor income of $\$ 395$ the first year and $\$ 85$ the second.

The returns per man day's work on crops and livestock on the 20 farms with the largest number of cattle units per farm were $\$ 5$ per day the first year, and $\$ 4.16$ the second, as compared with $\$ 1.27$ and $\$ 1.74$ on the 20 farms with the smallest number of cattle units per farm. The 49 farms with the larger number of cattle units per farm had re-

TABLE 10.-Cattle Units per Farm and Utilization of Labor (98 Beef Farms 1914-15 and 1915-16).

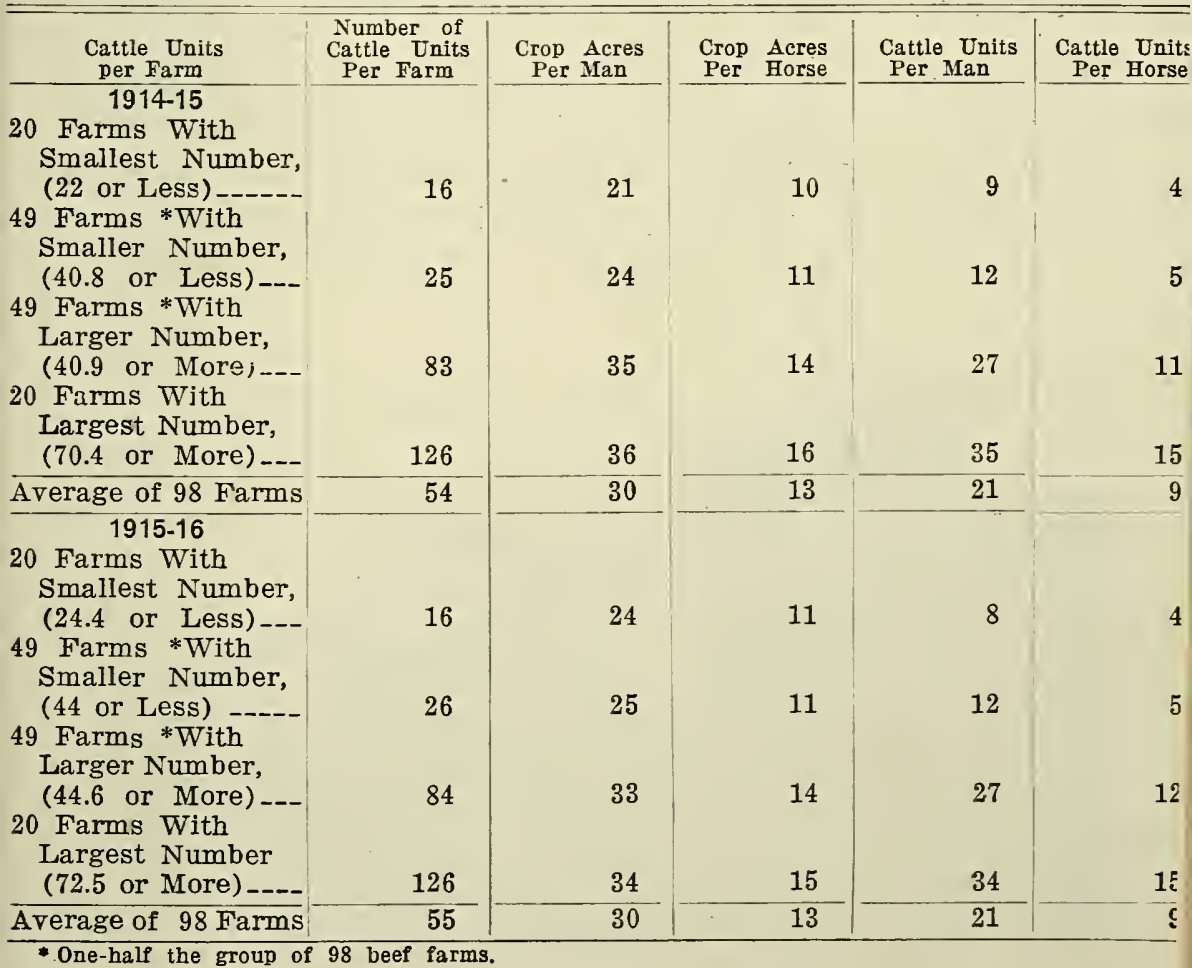


turns of $\$ 4.14$ per man days work the first year and $\$ 3.81$ the second, as compared with $\$ 2.51$ and $\$ 2.55$ on the 49 farms with the smaller number of cattle units per farm. A large farm business makes possible various economies in management, operation and organization that are usually impossible on a small farm.

Utilization of Labor.-The more efficient utilization of labor is one of the most important economies in the operation of a farm.

Table 10 shows that much more work was performed per man and horse on the farms with a large number of cattle units per farm than on those with a small number. There were nearly 50 percent more crop acres cared for per man on the 20 farms with largest number of cattle units per farm than on the 20 with smallest number. One man cared for 35 cattle units on the 20 farms with largest number of cattle units per farm, as compared with 9 cattle units on the 20 farms with smallest number.

Production.-The income per cattle unit and the yield of important crops did not seem to be affected by the size of farm business.

Distribution of Capital.-The 20 farms with the largest number of cattle units per farm the first year had the largest total amount of

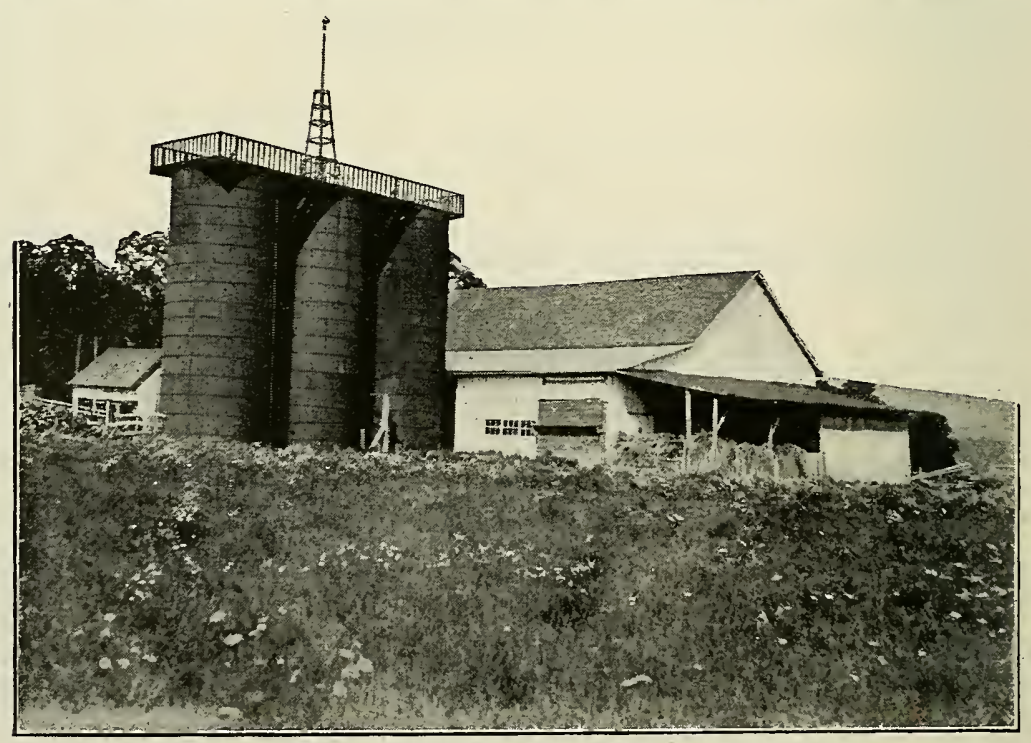

Where the Corn Crop is Turned Into Winter Feed. 
capital, $\$ 45,79 \%$, and also the largest proportion of their capital in working capital. About 25 percent of total capital was in the form of working capital. The 20 farms with the smallest number of cattle units per farm the first year had a total investment of $\$ 9,152$, or about 19 percent of the total capital was in the form of working capital; the next year there was a slightly smaller proportion in working capital.

Diversification.-The farms with the small number of cattle units per farm were more diversified than those with a larger number. In 1914-15 the 20 farms with the largest number of cattle units per farm averaged 73 percent of total receipts from cattle as compared with 57 percent for the 20 farms with the smallest number. The proportion of total returns from sales of crops was practically the same for farms of all sizes.

Receipts, Labor Income, and Family Income.-The average receipts per farm for the two years was $\$ 25 \% 4$, labor income $\$ 94$, and family income $\$ 1590$.

TABLE 11.-Total Receipts, Labor Income, and Family Income (98 Beef Farms 1914-15 and 1915-16).

\begin{tabular}{|c|c|c|c|c|}
\hline Total Receipts & $\begin{array}{c}\text { Number of } \\
\text { Farms }\end{array}$ & $\begin{array}{c}\text { Average Receipts } \\
\text { per Farm }\end{array}$ & $\begin{array}{l}\text { Labor } \\
\text { Income }\end{array}$ & $\begin{array}{l}\text { Family } \\
\text { Income }\end{array}$ \\
\hline $\begin{array}{l}1914-15 \\
\$ 1,000 \text { or less } \\
1,001 \text { to } 1,600 \ldots \\
1,601 \text { to } 2,400 \ldots \\
2,401 \text { to } 3,400 \ldots- \\
3,401 \text { or more }\end{array}$ & $\begin{array}{l}16 \\
22 \\
20 \\
19 \\
21\end{array}$ & $\begin{array}{r}\$ 644 \\
1327 \\
2036 \\
2738 \\
5859\end{array}$ & $\begin{array}{r}\$-236 \\
-173 \\
-80 \\
42 \\
1152\end{array}$ & $\begin{array}{r}\$ 288 \\
779 \\
1227 \\
1749 \\
5 \times 92\end{array}$ \\
\hline Average -..-.-. & 98 & 2605 & $161^{\circ}$ & 1646 \\
\hline $\begin{array}{l}1915-16 \\
\$ 1,000 \text { or less } \\
1,001 \text { to } 1,600 \ldots \\
1,601 \text { to } 2,400 \ldots \\
2,401 \text { to } 3,400 \ldots \\
3,401 \text { or more.-- }\end{array}$ & $\begin{array}{l}16 \\
19 \\
21 \\
20 \\
22\end{array}$ & $\begin{array}{r}590 \\
1311 \\
1962 \\
2841 \\
5313\end{array}$ & $\begin{array}{r}-461 \\
-289 \\
-50 \\
285 \\
491\end{array}$ & $\begin{array}{r}246 \\
567 \\
216 \\
1703 \\
8372\end{array}$ \\
\hline$\overline{\text { Average _-_- }}$ & 98 & 2543 & 27 & 1533 \\
\hline
\end{tabular}

Table 11 shows the relation of receipts to labor income and family income on farms with different total receipts. As the total receipts per farm increased, the labor income and family income also increased both years. 
Production.-There was no direct relationship between crop index and labor income either year. There was a general relationship between income per cattle unit and both labor income and family income.

TABLE 12.-Income per Cattle Unit, Labor Income, and Family Income

(98 Beef Farms 1914-15 and 1915-16).

\begin{tabular}{|c|c|c|c|c|}
\hline $\begin{array}{l}\text { Income per } \\
\text { Cattle Unit }\end{array}$ & $\underset{\text { Farms }}{\text { Number of }}$ & $\begin{array}{l}\text { Average Income } \\
\text { per Cattle Unit }\end{array}$ & $\begin{array}{l}\text { Labor } \\
\text { Income }\end{array}$ & $\begin{array}{l}\text { Family } \\
\text { Income }\end{array}$ \\
\hline $\begin{array}{l}1914-15 \\
\$ 18 \text { or less } \\
18.1 \text { to } 25 \\
25.1 \text { to } 32 \\
\text { More than } 32\end{array}$ & $\begin{array}{r}3 \\
19 \\
32 \\
44\end{array}$ & $\begin{array}{r}\$ 13.40 \\
21.60 \\
29.00 \\
39.50\end{array}$ & $\begin{array}{r}\$-914 \\
-86 \\
100 \\
398\end{array}$ & $\begin{array}{r}-54 \\
1086 \\
1678 \\
1752\end{array}$ \\
\hline Average ---.-- & 98 & 31.80 & 161 & 1646 \\
\hline $\begin{array}{l}1915-16 \\
\$ 18 \text { or less } \\
18.1 \text { to } 25 \ldots \ldots \\
25.1 \text { to } 32 \ldots \\
\text { More than } 32 \ldots\end{array}$ & $\begin{array}{c}21 \\
20 \\
23 \\
34\end{array}$ & $\begin{array}{l}13.00 \\
22.00 \\
28.50 \\
42.30\end{array}$ & $\begin{array}{r}-747 \\
63 \\
42 \\
502\end{array}$ & $\begin{array}{r}689 \\
1289 \\
1641 \\
2126\end{array}$ \\
\hline Average -...... & 98 & 28.50 & 27 & 1533 \\
\hline
\end{tabular}

Table 12 shows the relationship between receipts per cattle unit and labor income and family income on the 98 beef farms. In general, it may be said that the farms that had the largest income per cattle unit had the largest incomes. The farms with less than $\$ 25$ receipts per cattle unit did not average a positive labor income either year. The average income per cattle unit was $\$ 31.80$ the first year and $\$ 28.50$ the second year.

Utilization of Capital.- The utilization of capital was an important factor affecting labor income on the beef farms. If too large a proportion of the total capital is invested in fixed capital there is not sufficient capital remaining to purchase such items as cattle, feed, fertilizer, and machinery. 
TABLE 13.-Percentage of Total Capital in Working Capital, Labor Income, and Family Income

(98 Beef Farms 1914-15 and 1915-16).

\begin{tabular}{|c|c|c|c|c|}
\hline $\begin{array}{c}\begin{array}{c}\text { Percent of Total } \\
\text { Capital. in Working } \\
\text { Capital }\end{array} \\
\end{array}$ & $\underset{\text { Farms }}{\text { Number }}$ of & $\begin{array}{c}\text { Percent of Total Capi- } \\
\text { tal in Working } \\
\text { Capital }\end{array}$ & $\begin{array}{l}\text { Labor } \\
\text { Income }\end{array}$ & $\begin{array}{l}\text { Family } \\
\text { Income }\end{array}$ \\
\hline $\begin{array}{l}1914-15 \\
15 \text { or less } \\
15.1 \text { to } 20 \\
20.1 \text { to } 25 \\
\text { More than } 25\end{array}$ & $\begin{array}{l}19 \\
25 \\
30 \\
24 \\
\end{array}$ & $\begin{array}{l}12.0 \\
17.6 \\
22.3 \\
32.2\end{array}$ & $\begin{array}{r}\$-639 \\
66 \\
137 \\
924\end{array}$ & $\begin{array}{r}\$ 1156 \\
1479 \\
1602 \\
2260\end{array}$ \\
\hline Averago -..-- & 98 & 21.5 & 161 & 1646 \\
\hline $\begin{array}{l}1915-16 \\
1.5 \text { or less } \\
15.1 \text { to } 20 \\
20.1 \text { to } 25 \\
\text { More than } 25\end{array}$ & $\begin{array}{l}16 \\
26 \\
26 \\
30\end{array}$ & $\begin{array}{l}12.2 \\
17.9 \\
22.4 \\
37.8\end{array}$ & $\begin{array}{r}-642 \\
-38 \\
242 \\
251\end{array}$ & $\begin{array}{l}1174 \\
1435 \\
1515 \\
1827\end{array}$ \\
\hline$\overline{\text { Average_-----_--- }}$ & 98 & 22.7 & 27 & 1533 \\
\hline
\end{tabular}

Table 13 shows that both labor income and family income per farm increased as the percentage of total capital in working capital increased. The farms that had less than 15 percent of total capital in working capital made an average labor income of (minus) - $\$ 640$.

\section{Summary of the Beef Farms}

The size of farm business was the most important factor affecting earnings. A large farm business tends to make possible the other economies that are essential to a well organized and profitable farm. Size of farm business was directly correlated with such other factors as utilization of labor, utilization of crop and pasture land, percentage of total capital invested in working capital, and diversity. There was, however, no correlation shown between size of farm business and crop yields and income per animal unit. Utilization of man and horse labor, and income per cattle unit were important factors. The smallest unit for a profitable farn where beef cattle was the chief enterprise was about 100 beef cattle, 50 to 75 sheep, 3 to 5 dairy cows, 2 colts, 5 horses and 100 hens. Under ordinary conditions with the usual crops of the region it would require about 125 acres of crops to supply the winter feed for this amount of livestock and probably 350 to 500 acres of pasture. Some more intensive enterprise should be combined with the production of beef cattle and sheep on the smaller farms. Practically all of the crops grown on the beef farms, except wheat, were marketed through livestock. 


\section{GENERAL FARMS}

In the comparative study of the three types the general farms stood out as the least profitable. When the size of farm business was considered, the general farms were the smallest. They made the least efficient use of labor and had the lowest crop yields. The general farms had about the same number of acres of owned land as the dairy farms, but less than half the business and two-thirds the capital invested. The average general farm did not have a farm business iarge enough to produce a sufficient quantity of farm products to sell.

\section{TABLE 14.-Farm Receipts, Labor Income, and Family Income} (121 General Farms 1914-15 and 1915-16).

\begin{tabular}{|c|c|c|c|c|}
\hline Receipts & $\underset{\text { Farms }}{\text { Number }}$ & $\begin{array}{l}\text { Average Receipts } \\
\text { per Farm }\end{array}$ & $\begin{array}{l}\text { Labor } \\
\text { Income }\end{array}$ & $\begin{array}{l}\text { Family } \\
\text { Income }\end{array}$ \\
\hline $\begin{array}{l}1914-15 \\
\$ 300 \text { or less } \\
301 \text { to } 600 \\
601 \text { to } 1000 \\
1001 \text { to } 1500 \\
\text { More than } 1500\end{array}$ & $\begin{array}{l}28 \\
32 \\
27 \\
20 \\
14\end{array}$ & $\begin{array}{r}\$ 212 \\
430 \\
795 \\
1213 \\
2083\end{array}$ & $\begin{array}{r}\$-309 \\
-136 \\
-152 \\
-286 \\
192\end{array}$ & $\begin{array}{r}\$ 51 \\
214 \\
447 \\
591 \\
1286\end{array}$ \\
\hline Average -.-.-- & 121 & 782 & -166 & 415 \\
\hline $\begin{array}{l}1915-16 \\
\$ 300 \text { or less } \\
301 \text { to } 600 \\
601 \text { to } 1000 \\
1001 \text { to } 1500 \\
\text { More than } 1500\end{array}$ & $\begin{array}{l}16 \\
28 \\
27 \\
30 \\
20\end{array}$ & $\begin{array}{r}166 \\
491 \\
822 \\
1245 \\
2401\end{array}$ & $\begin{array}{r} \\
-231 \\
-66 \\
14 \\
58 \\
482\end{array}$ & $\begin{array}{r}38 \\
289 \\
523 \\
622 \\
1881\end{array}$ \\
\hline Average & 121 & 1025 & 52 & 654 \\
\hline
\end{tabular}

Table 14 shows the labor income and family income on the groups of farms with different amounts of farm receipts. Low crop yields made 1914-15 an unprofitable year for the general farms where crop production was the most important enterprise. The first year there was no consistent relation shown between receipts and labor income. In 1915-16 there was a definite increase in labor income and family income as receipts per farm increased. 


\section{Summary of the General Farms}

The average general farm was not profitable during either year of the survey. Even when the farm was owned by the operator free of debt, the farm earnings were hardly sufficient to maintain a desirable standard of living for the farmer and his family. The crop yields were low and farm business too small. Some of the farmers have met the need for a larger business by intensifying the enterprises already on the farm, by adding other intensive enterprises, and by buying or renting additional land. The total number of animal units on the dairy farm was nearly double the number kept on the general farm of the same number of acres.

\section{DAIRY FARMS}

There were only 20 farms of the 260 included in this survey that were dairy farms. The dairy farms contained about the same number of acres per farm as the general farms and about one-third as many as the beef farms.

The following table shows the general range of labor income on these 20 farms for both years.

\section{TABLE 15.-Range of Labor Income (20 Dairy Farms 1914-15 and 1915-16).}

\begin{tabular}{|c|c|c|c|c|}
\hline \multirow{2}{*}{ Labor Income } & \multicolumn{2}{|c|}{$1914-15$} & \multicolumn{2}{|c|}{1915.16} \\
\hline & $\begin{array}{c}\text { Number of } \\
\text { Farms }\end{array}$ & $\begin{array}{c}\text { Labor Income } \\
\text { per Farm }\end{array}$ & $\begin{array}{c}\text { Number of } \\
\text { Farms }\end{array}$ & $\begin{array}{c}\text { Labor Income } \\
\text { per Farm }\end{array}$ \\
\hline$\overline{\text { Less than } \$ 1_{\ldots}--}$ & 9 & $\$-311$ & 8 & $\$-319$ \\
\hline 1 to 500 & 6 & 198 & 3 & 109 \\
\hline 501 to $\$ 1000$ & 2 & 814 & 5 & 710 \\
\hline 1001 to 2000 & 2 & 1680 & 2 & 1126 \\
\hline More than 2000 & 1 & 2034 & 2 & 2824 \\
\hline Average _..... & 20 & 264 & 20 & 470 \\
\hline
\end{tabular}

Five farms the first year and nine the second made labor incomes of more than $\$ 500$; and one farm the first year and two the second made labor incomes of more than $\$ 2000$. While dairying was the most profitable of the three types, it was not extensively practiced because markets for milk and cream were unsatisfactory, and it was difficult to secure satisfactory labor for milking and caring for cows. Most of the less successful dairy farmers were general farmers, who were keeping cows and beginning to sell milk and cream as a means 


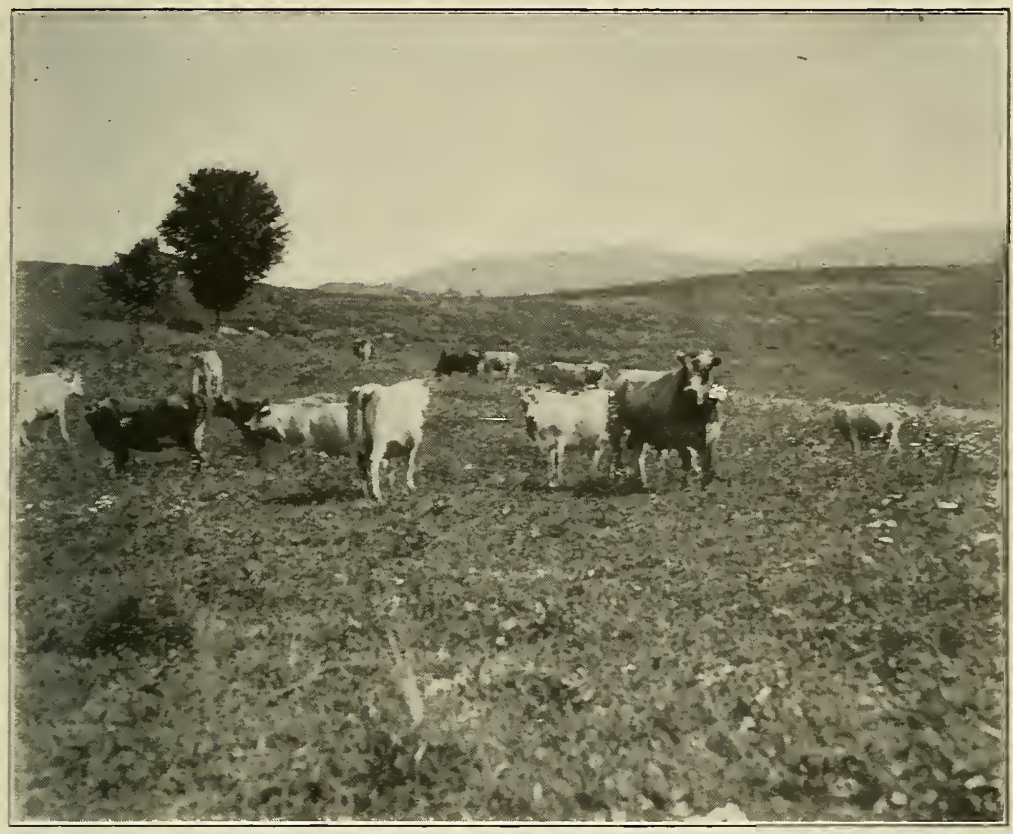

A Herd of Good Dairy Animals.

There were three small farms each year that sold butter. The other farms sold cream and whole milk mostly. On an average for toth years the farms that sold butter did not make 5 percent interest on investment.

\section{Summary of the Dairy Farms}

Dairying was the most profitable of the three types of farming. Lack of markets limited the development of dairy farming. The larger dairy farmers made reasonably good labor incomes. Most of the farms in this region were large enough, if properly handled, to support a dairy herd of such size as to be profitable.

\section{ONE AND TWO-YEAR SURVEYS}

In this study, data for either year show the same general tendencies as the average of both years. There seems to be very little justification for making a survey for two consecutive years, if 
the years are normal, to obtain a knowledge of farm management practiced in a region and to determine the factors contributing to profitable farming. Records were taken for two consecutive years for this study because the first year of the survey, 1914, was not a normal year for crop production. The rainfall of May and June together in 1914 was 24 inches, in 1915 it was 6.95 inches (see Table 1). The growing season in 1914 was 15 days shorter than normal. Crop yields were much lower in 1914 than in 1915 (see Table 5). In 1915 bluegrass pasture was light as a result of the drouth in 1914. Tables 11 to 14 show the variation in the number of farms in the classification groups for the two years. Conclusions based on a study of data for 1914 would be misleading as to crop yields, which in turn, materially influence returns from farming. 

